\title{
STRUCTURAL CHANGE AND THE KALDOR FACTS IN A GROWTH MODEL WITH RELATIVE PRICE EFFECTS AND NON-GORMAN PREFERENCES
}

\begin{abstract}
BY TIMO BOPPART ${ }^{1}$
U.S. data reveal three facts: (1) the share of goods in total expenditure declines at a constant rate over time, (2) the price of goods relative to services declines at a constant rate over time, and (3) poor households spend a larger fraction of their budget on goods than do rich households. I provide a macroeconomic model with non-Gorman preferences that rationalizes these facts, along with the aggregate Kaldor facts. The model is parsimonious and admits an analytical solution. Its functional form allows a decomposition of U.S. structural change into an income and substitution effect. Estimates from micro data show each of these effects to be of roughly equal importance.
\end{abstract}

KEYWORDS: Structural change, structural transformation, relative price effect, nonGorman preferences, Kaldor facts.

\section{INTRODUCTION}

IT IS WELL DOCUMENTED THAT ECONOMIC GROWTH GOES HAND IN HAND with significant shifts in the sectoral structure of output, employment, and expenditures (Kuznets (1957)). These dynamics are hard to square with balanced growth at the aggregate level, as described by the Kaldor facts-that is, the growth rate of real per-capita output, the real interest rate, the capital-output ratio, and the labor income share are all constant over time (Kaldor (1961)).

Structural change in expenditures is commonly believed to be driven by two separate forces. First, the expenditure structure can shift because of relative price changes driven by asymmetric technologies across sectors. ${ }^{2}$ Second, an income effect may decrease the expenditure shares of necessities (and increase

${ }^{1}$ I would like to thank Josef Falkinger, Reto Föllmi, Volker Grossmann, Marcus Hagedorn, Tim Kehoe, Per Krusell, Kiminori Matsuyama, Rachel Ngai, Sergio Rebelo, Danyang Xie, Fabrizio Zilibotti, and Josef Zweimüller for illuminating discussions. Moreover, I would like to thank Simon Alder, Orazio Attanasio, Gregori Baetschmann, Konrad Burchardi, Pierre-André Chiappori, Tom Cunningham, Victoria Galsband, Sandra Hanslin, Andreas Müller, Nick Netzer, Torsten Persson, Iryna Stewen, Raphael Studer, Franziska Weiss, the editor, three anonymous referees, and participants at the annual congress of the Royal Economic Society 2011, EEA 2011, and ES in Evanston 2012 as well as participants at University of Zurich, IIES, Stockholm University, Nordic Macro Symposium 2011, the workshop on dynamic macro in Vigo 2012, NBER SI 2012, and the workshop on structural change at Surrey University 2012 for many valuable comments and suggestions. Marc Bill, Lukas Gehrig, and Theo Süllow provided excellent research assistance. I thank Annika Andreasson for her proof-reading. An earlier version of this paper is part of my cumulative dissertation at University of Zurich.

${ }^{2}$ This mechanism goes back to Baumol (1967), who stressed productivity growth differentials as a source of relative price changes. Changes in relative prices affect expenditure shares whenever the elasticity of substitution across sectors is not equal to unity. 